\title{
In Vivo Expression of $\beta$-Galactosidase in Hippocampal Neurons by HSV-Mediated Gene Transfer
}

\author{
DAVID J. FINK, ${ }^{1}$ LAWRENCE R. STERNBERG, ${ }^{2,4}$ PETER C. WEBER,${ }^{2,3}$ MARINA MATA, ${ }^{1}$ \\ WILLIAM F. GOINS ${ }^{4}$ and JOSEPH C. GLORIOSO ${ }^{4}$
}

\begin{abstract}
Stereotactic inoculation of a herpes simplex virus (HSV) gene transfer vector into the hippocampus and caudate of rat brain resulted in limited and transient viral replication and the establishment of latency. Virus attenuation was achieved by insertional inactivation of a viral gene, Us3. Insertion of a lac $Z$ reporter gene, under the control of the HSV glycoprotein $\mathrm{C}(\mathrm{gC})$ late gene promoter, allowed viral replication to be monitored in vivo. Unlike unattenuated virus, the Us3::pgC-lacZ recombinant caused little apparent damage to normal hippocampal morphology. Transient lac Z expression was detected in a considerable population of neurons of the dentate gyrus following hippocampal injection, whereas few positively staining neurons were present within the caudate after injection at that site. Latency-associated transcripts, the hallmark of latent infection, were detected in the brain 10 months after injection. This recombinant virus may be useful as a gene transfer vector for long-term expression of foreign genes in the central nervous system.
\end{abstract}

\section{OVERVIEW SUMMARY}

Development of suitable vectors for transfer of genes to the central nervous system (CNS) is an active field of research. Fink et al. have determined that disruption of a herpes simplex virus (HSV) protein kinase gene (Us3) results in significant virus attenuation and prevents spread in the CNS, and that this mutant virus can establish long-term latency in the brain. These results suggest that this vector should be useful for expression of foreign genes in neurons localized to precise regions of the brain following stereotactic vector delivery.

\section{INTRODUCTION}

$\mathbf{H}$ ERPES SIMPLEX VIRUS (HSV) is a neurotropic virus, which in natural infection is taken up by axonal terminals and transported retrogradely to the neuronal cell body (Hill, 1985).
The virus can establish long-term latency in which the viral genomes persist in a circular or concatameric extrachromosomal state (Rock and Fraser, 1983; Efstathious et al., 1986; Mellerick and Fraser, 1987). Latency normally occurs in peripheral sensory ganglia following primary infection of the skin or mucosal surfaces. In animal models, infection of peripheral sensory ganglia can be achieved by inoculation of the skin, cornea, or the olfactory bulb (Cook and Stevens, 1973; Stroop and Schaefer, 1987). Focal HSV infection of specific brain regions can be achieved by stereotactic injection of small volumes of virus into specific brain regions (Bak et al., 1977; McFarland et al., 1986). The establishment of latent virus infection of very limited brain components has been reported using defective and attenuated virus vectors in site specific infections (Chiocca et al., 1990). It remains to be determined whether direct inoculation of attenuated virus results in latency in a limited brain location. Moreover, the potential pathological effects of attenuated virus injection into specific brain regions have not been studied long term.

Latently infected neurons show an extremely restricted and characteristic pattern of viral gene expression (Hill, 1985;

\footnotetext{
${ }^{1}$ Department of Neurology and VA Medical Center, ${ }^{2}$ Department of Microbiology and Immunology, University of Michigan, Ann Arbor, MI 48105 .

${ }^{3}$ Department of Microbiology and Immunology, The Pennsylvania State University at Hershey, Hershey, PA 17033.

${ }^{4}$ Department of Molecular Genetics and Biochemistry University of Pittsburgh School of Medicine, Pittsburgh, PA 15261 .
} 
Stevens, 1989). The only transcriptionally active region of the viral genome maps to a segment of the inverted repeat sequences of the long unique $\left(\mathrm{U}_{\mathrm{L}}\right)$ region of the viral genome just downstream of the structural gene for infected cell polypeptide $\mathrm{O}$ (ICPO). The detected RNA species are transcribed off of the opposite strand from ICPO and are therefore partially complementary to the ICPO mRNA. The most abundant transcripts are 1.8 to $2.3 \mathrm{~kb}$ in size and have been designated collectively as latency-associated transcripts, or LATs (Deatly et al., 1987; Puga and Notkins, 1987; Rock et al., 1987; Spivack and Fraser, 1987; Stevens et al., 1987; Wagner et al., 1988). It remains to be proven whether any of the LATs encode a viral protein. Deletions within LAT do not alter the ability of the virus to establish or maintain latency; however, reactivation appears to be impaired among certain LAT $^{-}$mutants (Ho and Mocarski, 1989; Leib et al., 1989; Sederati et al., 1989; Steiner et al., 1989).

This set of features - a virus targeted to neuronal tissues that is capable of naturally entering a latent state whereby it expresses a limited portion of its genome-suggests that HSV may potentially represent an ideal shuttle vector for delivery of foreign genes into the central nervous system (CNS) (Breakefield and Geller, 1987; Freese et al., 1990).

Previous attempts to develop an HSV vector for effective gene transfer into mammalian neurons have used two alternative approaches. Packaged defective HSV-1 amplicons have been used to express foreign genes in cultured peripheral nervous system (PNS) (Geller and Breakefield, 1988) and CNS (Geller and Freese, 1990) neurons. However, the ability of these vectors to express foreign genes in vivo has not been demonstrated. Alternately, HSV vectors derived from virus defective in an immediate early gene required for viral replication (ICP4) have been demonstrated to be capable of mediating long-term expression of foreign gene products in dorsal root ganglia after sciatic nerve inoculation (Dobson et al., 1990), trigeminal ganglia after corneal scarification (R.L. Hendricks, L.R. Sternberg, W.F. Goins, and J.C. Glorioso, in preparation), and neurons in the hypoglossal nucleus after injection of the tongue (Dobson et al., 1990).

Although these approaches demonstrate the promise of using HSV for the expression of foreign genes in neuronal structures, a completely defective virus may be limited as a gene transfer vector due to the small number of neuronal cells in which the vector may establish latency. An alternative approach employs the development of replicating, but highly attenuated, strains of HSV which may be capable of establishing latency in a greater number of neurons without causing neuropathologic damage.

Previously, we and others have determined that viruses defective in several individual genes in the unique short $\left(U_{S}\right)$ region of the HSV-1 genome show significantly reduced pathogenicity following intracranial inoculation (Weber et al., 1987; Meignier et al., 1988). Previous DNA sequence (McGeoch and Davidson, 1986), immunological (Purves et al., 1987), and mutational (Leader and Katan, 1988) analyses have demonstrated that one of the open reading frames, the Us3 gene, encodes a protein kinase (for review, see Leader and Purves, 1988) whose physiological substrate has recently been identified as HSV-1 UL34 phosphoprotein (Purves et al., 1991). The Us3 gene is dispensable for virus replication in cell culture (Longnecker and Roizman, 1987; Meignier et al., 1988) and for the establishment of latent infection in the murine PNS; however, the ability of a Us 3 mutant to establish latency in the CNS has not been evaluated.

In the present report, we demonstrate that this vector can be used to express a foreign gene in a discrete region of rat brain, that it causes limited neuropathologic damage, and that it establishes long-term latency in the CNS following intracranial inoculation. These results suggest that this attenuated mutant may function as an effective gene transfer vector.

\section{MATERIALS AND METHODS}

\section{Construction of the Us3::pgC-lacZ recombinant}

The lac $Z$ gene was placed under the regulatory control of a well-characterized HSV-1 late gene promoter, that of the glycoprotein $\mathrm{C}(\mathrm{gC})$ gene (Homa et al., 1986), ensuring that the $\beta$-galactosidase gene product would be expressed at high levels during lytic infection. The reporter gene cassette was constructed in such a way that lacZ gene, gC promoter ( -144 to +124 ), and an SV40 polyadenylation signal can be removed as

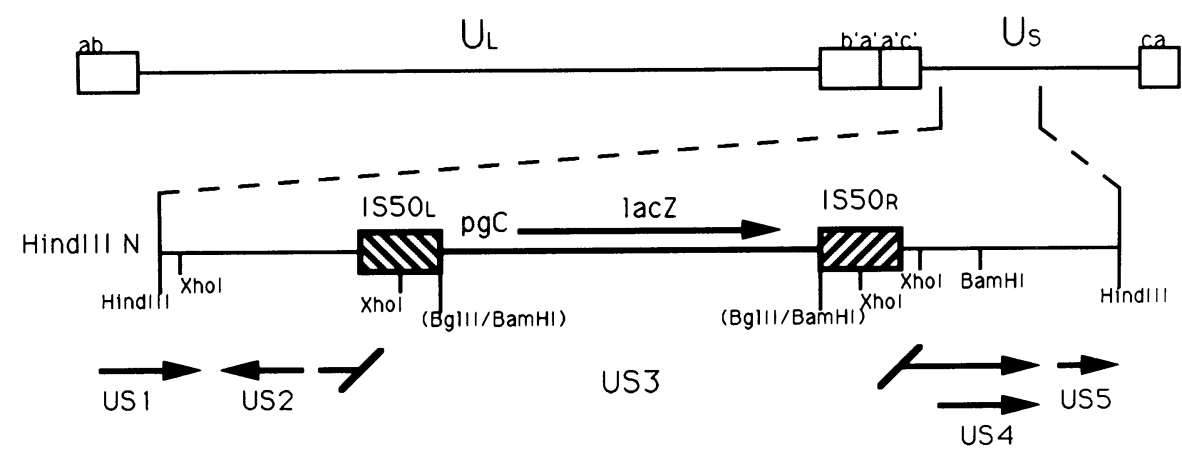

FIG. 1. Schematic representation of HSV Us3::pgC-lacZ genome, indicating the location of the pgC-lacZ reporter cassette. The pgC-lacZ reporter cassette was cloned as a 4.2-kb Bam HI fragment into the $B g l$ II sites of the Tn 5 located within the IS50 repeat elements, replacing the internal Tn5 sequence. The presence and precise mapping of the Tn5::gC-lacZ cassette within the Us3 locus (Hendricks et al., 1991) was confirmed by Southern blot analysis (Goins and Stinski, 1986). In vitro infection with the recombinant produces blue plaques following X-gal agarose overlay (Ho and Mocarski, 1989). 


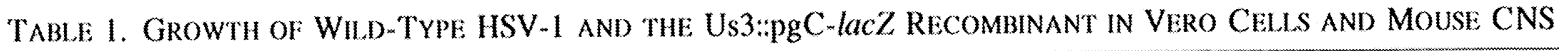

\begin{tabular}{|c|c|c|c|c|c|}
\hline \multirow[b]{3}{*}{ Virus } & \multicolumn{4}{|c|}{ Vero cells in vitro } & \multirow{3}{*}{$\begin{array}{c}\begin{array}{c}\text { Mouse CNS } \\
\text { in vivo }\end{array} \\
\begin{array}{c}L D_{50} \text { titer }^{x} \\
\text { in mice }\end{array}\end{array}$} \\
\hline & \multicolumn{2}{|c|}{$m o i=1.0$} & \multicolumn{2}{|c|}{$m o i=0.1$} & \\
\hline & $\begin{array}{c}\text { Titer } \\
(p f u / m l)^{a}\end{array}$ & $\begin{array}{l}\text { Fold reduction } \\
\quad \text { in yield }\end{array}$ & $\begin{array}{c}\text { Titer } \\
(p f u / m l)^{a}\end{array}$ & $\begin{array}{l}\text { Fold reduction } \\
\quad \text { in yield }\end{array}$ & \\
\hline HSV-1 (KOS) & $4.3 \times 10^{8}$ & $\cdots$ & $4.7 \times 10^{8}$ & - & $10^{1.0}$ \\
\hline HSV-1 (Us3:pgC-lacZ) & $6.0 \times 10^{7}$ & 7.2 & $4.7 \times 10^{7}$ & 10.0 & $10^{4.6}$ \\
\hline
\end{tabular}

aTiters represent the yield of virus from a $60-\mathrm{mm}$ dish of Vero cells infected at the indicated multiplicity. (moi, multiplicity of infection; pfu, plaque-forming units).

bTiters represent the median lethal dose $\left(L_{50}\right)$ of virus after intracerebral inoculation into DBA/2 mice, determined by techniques described in the Materials and Methods.

a single $4.2-\mathrm{kb}$ Bam HII restriction fragment, and inserted into a previously generated plasmid (Weber et al., 1987) containing a 'Tn5 insertion into the 5 ' end of the Us 3 open reading frame (McGeoch et al., 1985). The 4.2-kb Bam HI fragment was cloned into the $B g l$ II sites located within the IS 50 repeat elements of the TnS insertion within Us 3 in a manner so as to replace the internal $2.8-\mathrm{kb} \mathrm{Bgl}$ II fragment of the transposon
(Hendricks et al., 1991). The truncating nature of the TuS mutation is preserved in this construction since the $\mathrm{pgC}-\mathrm{lacZ}$ cassette does not alter the stop codons present within the trans. poson termini.

Infectious wild-type KOS strain HSV-1 viral DNA and Us3::pgC-lacZ plasmid DNA were cotransfected into Vero cells using the calcium phosphate procedure (Shapira et al.,

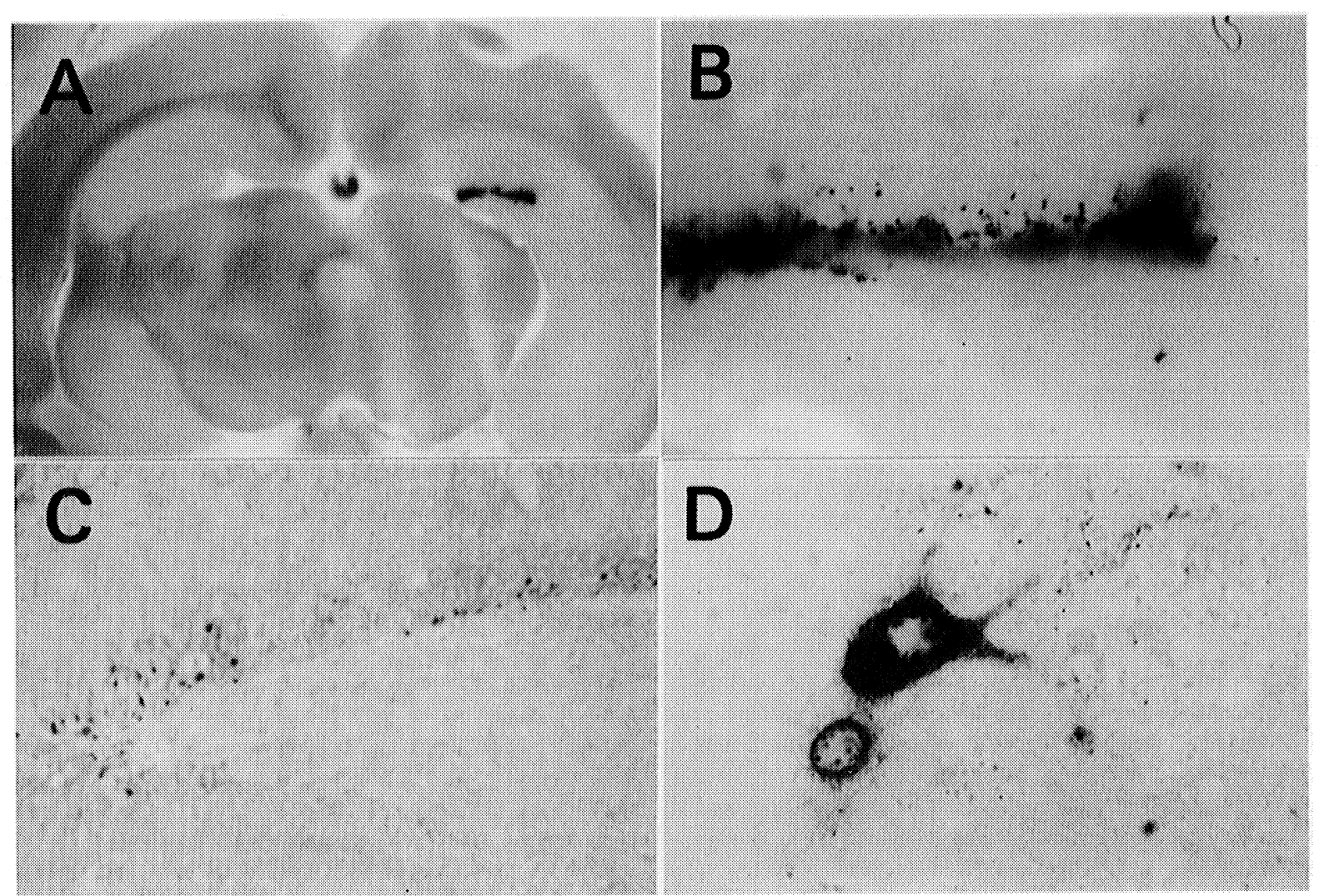

FIG. 2. Transgenic expression of $l a c Z$ in brain using the Us $3: 5 g C-l a c Z$ recombinant. A and B. X-gal staining of $100-\mu \mathrm{m}$ vibratome sections 2 days after inoculation of $5 \mu$ l containing $10^{8} \mathrm{pfu} / \mathrm{ml}$ of the Us $3: \mathrm{pgC}$-lacZ recombinant demonstrates blue cells unilaterally in injected hippocampus. A. Original magnification, $6 \times$. B. Original magnification, $50 \times$. C. Immunostaining with anti $\beta$-gal antibody shows staining confined to neurons in the dentate gyrus of the injected hippocampus (original magnification, $120 \times)$. D. Sections of $1 \mu \mathrm{m}$ embedded in plastic show that the vast majority of blue-staining cells had neuronal morphology (original magnification, $1,000 \times$ ). 
1987) and recombinants were detected using the blue plaque assay. Bricfly, progeny virus from transfections was plated out in suitable dilutions onto $60 \mathrm{~mm}$ dishes containing confluent Vero cell monolayers. After virus adsorption, the monolayers were overlaid with methylcellulose supplemented with $2 \%$ calf serum and plaques were allowed to develop over 3 days. The monolayers were then washed twice with PBS and overlaid with media containing $0.5 \%$ LMP-agarose ( $2 \%$ stock in water; BRL, Gaithersburg, MD) and $150 \mu \mathrm{g} / \mathrm{ml} \mathrm{X-gal} \mathrm{(2 \%} \mathrm{stock} \mathrm{in}$ dimethylformamide; BRL, Gathersburg, MD), Recombinant viruses could be detected by blue plaque formation within 24 to 48 hrs. These plaques were picked, resuspended in $1 \mathrm{ml}$ of media, and purified by the bluc plaque assay three rounds past the last appearance of white plaques in the viral stocks.

\section{Virulence determinations}

The median lethal doses $\left(\mathrm{LD}_{50}\right)$ of viruses after intracerebral inoculation into mice were determined by the methods of Sunstrum et al. (1988). Briefly, each of 10 DBA/2 mice (Jackson Laboratories, Bar Harbor, ME) was injected intracerebrally with virus doses ranging from $10^{1}$ to $10^{5}$ pfu in $\log _{10}$ increments. The animals were observed daily for signs of neurologic disease and eventual death due to viral encephalitis.

\section{$X-g a l$ staining}

Male Sprague Dawley rats (200-250 grams) were anesthetized with chloral hydrate and $1-10 \mu l$ of media containing $5 \times 10^{8} \mathrm{pfu} / \mathrm{ml}$ of virus was injected stereotactically unilaterally into the hippocampus or caudate using the coordinates in the atlas of Paxinos and Watson (1982). At the time of sacrifice the animals were reanesthetized and perfused with $4 \%$ paraformaldehyde, $0.4 \%$ glutaraldehyde. The brains were removed, post - fixed $2 \mathrm{hr}$ at $4^{\circ} \mathrm{C}$ in the same solution, and $100 \mu \mathrm{m}$ vibratome sections cut and reacted with $0.015 \%$ X-gal (BRL, Gaithersburg, MD) in $1 M$ Tris pH $8.0,12.5 \%$ DMSO, $53 \%$ $\mathrm{K}_{4} \mathrm{Fe}(\mathrm{CN})_{6}$, and $0.14 \% \mathrm{~K}_{3} \mathrm{Fe}(\mathrm{CN})_{6}$ for $21 \mathrm{hr}$ at $37^{\circ} \mathrm{C}$.

In some experiments the animals were anesthetized, and the brains were removed, frozen at $-70^{\circ} \mathrm{C}$, and $10 \mu \mathrm{m}$ cryostat sections post-fixed for $10 \mathrm{~min}$ with $4 \%$ paraformaldehyde followed by $\mathrm{X}$-gal staining as described above. These sections were counterstained with neutral red or cresyl violet as indicated.

\section{Immunocytochemistry}

The specificity of the X-gal reaction product was confirmed by immunocytochemistry. Floating $100 \mu \mu \mathrm{m}$ vibratome sections, fixed as for $X$-gal reaction, were reacted with a monoclonal antibody against $\beta$-galactosidase (Boehringer Mannhein, Indianapolis, IN) at dilutions of 1:50 to 1:500 and developed with avidin-biotin-peroxidase staining (Zymed Labs, San Francisco, CA).

\section{Electron microscopy}

Vibratome sections, stained with X-gal as described above, were further fixed overnight in $2 \%$ paraformaldehyde, $2 \%$ glutaraldehyde, dehydrated with a series of alcohol washes, and

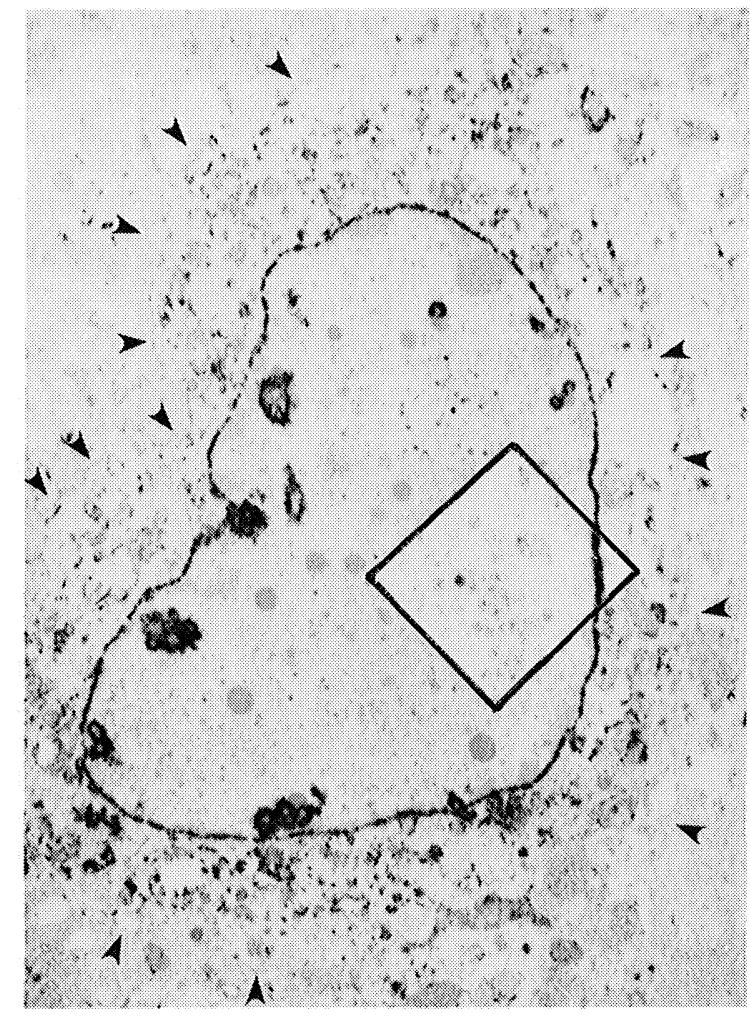

FIG. 3. Subcellular localization of X-gal reaction product and viral recombinant particles. Electron microscopy of hippocampus 2 days post-inoculation with Us3::pgC-lac\% shows electron-dense X-gal reaction product along the nuclear membrane and diffusely throughout the cytoplasm of this neuron (outlined with arrowheads). Nonenveloped viral particles are recognizable in the nucleus (enlarged in inset), but are not readily visible within the cytoplasm of the infected cell (original magnification, $14,400 \times$ ).

embedded in epon araldite. Semithin $(1 \mu \mathrm{m})$ and ultrathin sections were examined.

\section{Nucleic acid isolation}

Nucleic acid samples were isolated from brain paste created from minced cerebral hemispheres of infected animals. DNA samples were isolated using the Stratagene DNA Extraction Kit, (Stratagene, La Jolla, CA), according to the protocol provided. Precipitated DNA was resuspended in sterile TE. RNA samples were isolated using the RNAzol B RNA extraction kit (CINNA/BIOTECX Labs, Friendsword, TX) according to the protocol provided. Precipitated RNA was additionally treated with RNase-free DNase (BRL, Gaithersburg, MD), boiled, reprecipitated, and then resuspended in DEPC-treated $\mathrm{H}_{2} \mathrm{O}$. The same animals served as source for both DNA and RNA at a given time point.

\section{PCR analyses}

DNA and RNA PCR analyses were performed using three separate Us $3: \mathrm{pgC}$-lac $Z$ specific primer pairs. They were $\left(5^{\prime}\right.$ to 

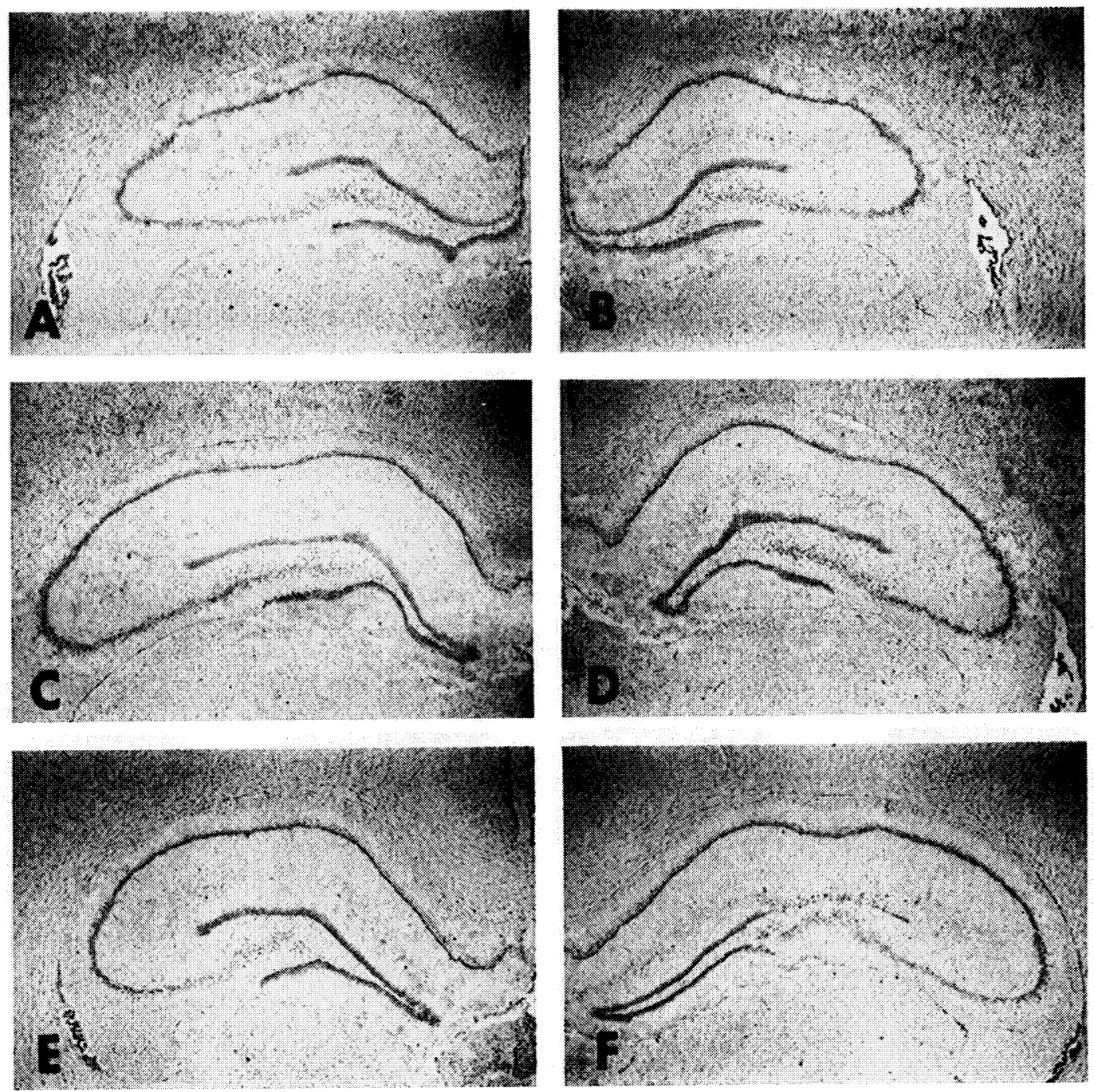

FIG. 4. Assessment of vector neuropathogenicity. Sections of injected $(B, C, F)$ and contralateral $(A, D, E)$ hippocampus 4 weeks after inoculation with $1 \mu \mathrm{l}$ of $10^{8} \mathrm{pfu} / \mathrm{ml}$ of the Us3::pgC-lacZ recombinant virus. A small area of neuronal cell loss in the dentate gyrus is seen at the point of the needle track in one brain $(F)$, but neuronal architecture is well preserved. These 10- $\mu \mathrm{m}$ sections from the brains of 2 animals, stained with X-gal, and counterstained with neutral red, showed no blue reaction product (original magnification, $12.5 \times$ ).

$\left.3^{\prime}\right)$ : LAT primer 1 (5' primer), GAC-AGC-AAA-AAT-CCCGTC-AG; LAT primer 2 (3' primer), ACG-AGG-GAA-AACAAT-AAG-GG (Lynas et al., 1989); lacZ primer 1 (5' primer), TTG-CTG-ATT-CGA-GGG-GTT-AAC-CGT-CACGAG; lacZ primer 2 (3' primer), ACC-AGA-TGA-TCA-CACTGC-GGT-GAT-TAC-GAT (Itakura, 1982); gB primer 1 (5' primer), ATT-CTC-CTC-CGA-CGC-CAT-ATC-CAC-CTT; gB primer 2 ( $3^{\prime}$ primer), AGA-AAG-CCC-CCA-TTG-GCCAGG-TAG-T (D.J. Dorney and J.C. Glorioso, unpublished data). PCR analyses were performed using the GeneAmp PCR Core Reagent kit (Perkin Elmer Cetus, Norwalk, CT) and a COY thermocycler (COY Inc., Ann Arbor, MI) according to protocols provided. For DNA PCR amplifications, the specific reaction conditions used were: (i) initial denaturation; $95^{\circ} \mathrm{C}, 4$ min; (ii) [anneal $50^{\circ} \mathrm{C}, 1 \mathrm{~min}$, extend $72^{\circ} \mathrm{C}, 1 \mathrm{~min}$ denature $\left.94^{\circ} \mathrm{C}, 1 \mathrm{~min}\right] \times 40$ cycles; (iii) final extension $72^{\circ} \mathrm{C}, 6 \mathrm{~min}$; (iv) hold at $4^{\circ} \mathrm{C}$ until gel electrophoresis. For RNA PCR analyses, the cDNA synthesis step was performed with the appropriate $3{ }^{\prime}$ primer of each primer set (primer \#2 of each respective set) and AMV reverse transcriptase (Promega Corp, Madison, WI) using the Promega cDNA synthesis kit (Promega, Madison, WI).

PCR products were analyzed on ethidium bromide stained 3\% NuSieve GTG agarose gels (FMC INC, Rockport, ME). Specificity of the bands generated by PCR was confirmed following rapid alkaline transfer (Hatcher et al., 1990) to nylon membranes (Schleicher \& Schuell, Keene, NH) using ${ }^{32} \mathrm{P}-$ labeled probes. Riboprobes capable of detecting each PCR product were generated using the Riboprobe Gemini System (Promega, Madison, WI). Template DNAs used in the synthesis were produced by PCR amplification of Us3::pgC-lacZ viral DNA using three additional $3^{\prime}$ primers identical in sequence to the LAT primer \#2, gB \#2, and LacZ\#2, but which 
also included the bacteriophage Sp6 promoter (Haggi ef al., 1988).

\section{RESULTS}

To assess the potential utility of a Us 3 mutant vinus as a gene transfer vector for the CNS, a virus recombinant designated Us 3::pgC-lacZ was constructed in which the lacZ gene under control of the viral late gene promoter of glycoprotein $\mathrm{C}(\mathrm{gC})$ was introduced into the Us 3 locus thereby interrupting the production of a functional Us3 gene product (Fig. 1). This virus recombinant produced large amounts of $\beta$-galactosidase as a late gene product during lytic infection and virus plaques in cell culture stained blue following $X$-gal agarose overlay (data not shown). Therefore, expression of lac' following intracranial inoc- ulation should demonstrate the extent of vinus spread and define the types of cells permissive for viral replication. Failure to detect $\beta$-gal upon introluction of vinus into the brain should indicate that infected cells could not support viral late gene expression and consequently infectious progeny could not be produced. Continued expression of lac $\%$ would indicate a persistent active infection. If lac $Z$ expression were transient and limited to the site of inoculation, latency might also be limited to a particular set of neurons at that site. Our previous studies have demonstrated the ability of wild-type HSV-1 (KOS) to replicate in neuronal cells of the limbic system with rapid development of encephalitis following intracerebral inoculation of mice (Sunstrum et al., 1988; Chrisp et al., 1989). Failure to disrupt the well-defined neuronal architecture of the hippocampus would therefore provide a convenient, easily defined measure of the pathogenic effects of the virus following intracranial inoculation.

\section{5 a}

DNA PCR wilacZ primors

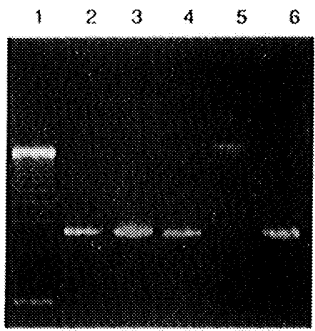

L $2710 \mathrm{U}+\mathrm{C}$

Southern blot probed with lacz riboprobe

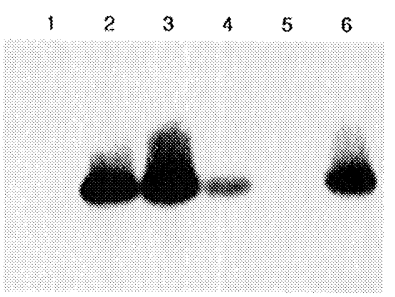

L $2710 \mathrm{U}+\mathrm{C}$ LacZ 324bp
$5 b$

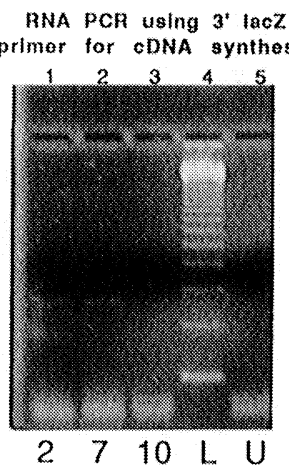

Southern blot probed with lacz rlboprobe

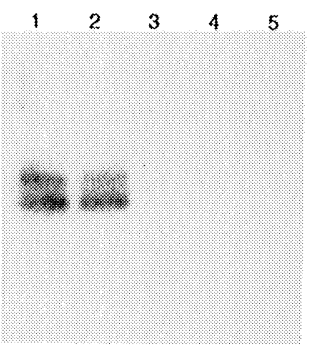

2710 L U LacZ 324bp
$5 \mathrm{c}$

RNA PCN using 3 LAT

primer for CDNA synthosis

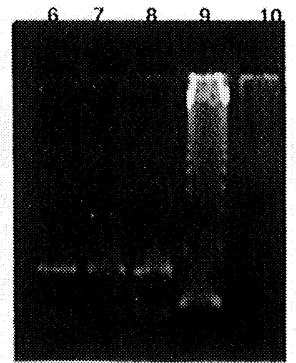

$2710 \mathrm{~L} \mathrm{U}$

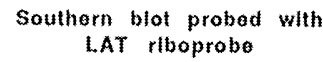

$67809-10$

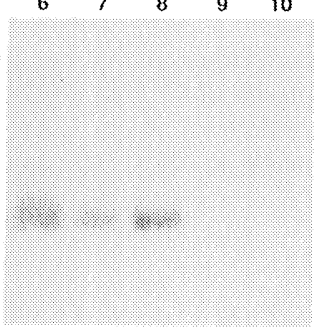

2710 L U

LAT $195 \mathrm{bp}$
$5 d$

ANA PCR using $3^{\prime} \mathrm{gB}$ primer for cDNA synthesis

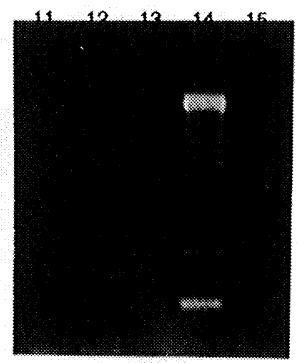

$2710 \mathrm{~L} \quad \mathrm{U}$

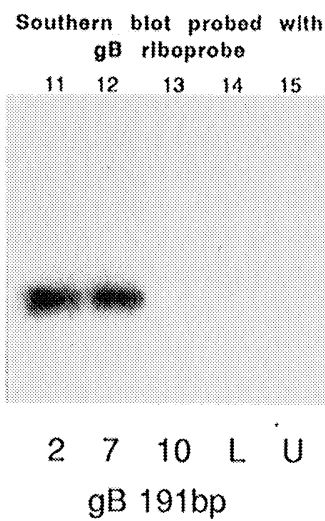

FIG. 5. PCR analysis of viral-specific DNA and RNA isolated from rat CNS following intracranial inoculation with Us $3:: p \mathrm{gC}$ lac Z. a, top. Gel electrophoresis of PCR products generated from $1.0 \mu \mathrm{g}$ of total DNA isolated from brain amplified using the lacZ primer pair (see Materials and Methods). Legend: 123-bp ladder (L); 2 days p.i. (2); 7 days p.i. (7); 10 months p.i. (10); uninfected control $(\mathrm{U})$; and positive control $(+\mathrm{C})$ using Us3::pgC $\mathrm{CaCZ}$ viral DNA as template a, bottom. Southern blot of the same samples probed with ${ }^{32}$ p-labeled lacZ-specific riboprobe. $\mathrm{b} \mathrm{d}$, top. Gel electrophoresis of PCR products generated from $1.0 \mu \mathrm{g}$ of RNA isolated from brain amplified 40 cycles with the primer pairs for lacZ (b), LAT (c), and gB (d). Legend: 2 days p.i. (2); 7 days p.i. (7); 10 months p.i. (10); 123-bp ladder (L); and uninfected control (U). b-d, bottom. Southern blots of the same gels probed, respectively, with ${ }^{32} \mathrm{P}$-labeled riboprobes for lac', LAT, and $\mathrm{gB}$. A second, highermolecular-weight band was reproducibly seen in Southern blots of RNA-generated, but not DNA-generated, lacZ PCR amplifications. The origin of this second band has not been determined; however, it may represent spurious hybridization of one primer of the lac $\%$ primer pair to a region approximately $50 \mathrm{bp}$ from the actual site of hybridization. 
In tissue culture, the Us3::pgC-lacZ recombinant replicated virtually as well as wild-type virus, but in vivo showed a 1,000fold increase in $\mathrm{LD}_{50}$ by direct intracranial inoculation of DBA/2 mice (Table 1). These findings are consistent with data from another Us3-defective mutant (Meignier et al., 1988). Additionally, Us3::pgC-lacZ displayed impaired replication in serum-starved tissue culture cells arrested in $\mathrm{G}_{0}$ (A.M. Bonneau, J. Chafouleas, J.C. Glorioso, unpublished data). To assess the behavior of this virus in the rat CNS, 1-10 $\mu$ l of media containing $10^{8} \mathrm{pfu} / \mathrm{ml}$ of virus was stereotactically injected unilaterally into the hippocampus or into hippocampus and contralateral caudate. A marked blue reaction product indicating $\beta$-gal production was seen in the injected hippocampus from 1 to 5 days after inoculation, most prominent at 2 and 3 days (Fig. 2A,B) extending throughout the dorsal hippocampus, at least 3 $\mathrm{mm}$ in a rostral-to-caudal direction. Staining disappeared completely by day 10 . Few blue neurons were detected in caudate indicating that the virus replicated poorly in this brain region. In cryostat sections counterstained with neutral red, blue cells were confined to the dentate gyrus of the injected hippocampus. Animals injected with an equivalent number of pfu of wild-type virus (KOS) showed an extensive inflammatory infiltrate at 2 days, but no evidence of blue reaction product upon $\mathrm{X}$-gal staining.

The presence of $\beta$-gal was confirmed by immunocytochemistry using alternate floating vibratome sections immunostained with a monoclonal antibody specific for $\beta$-gal. The immunostaining pattern was comparable to that seen with X-gal (Fig. $2 \mathrm{C}$ ). This result demonstrates that the cytochemical reaction product results from $\beta$-galactosidase gene expression from the virus genome. To determine the identity of the cells supporting $\beta$-galactosidase expression, semithin sections prepared from the vibratome sections were examined. The vast majority of cells containing X-gal reaction product were neurons (Fig. 2D) defined by their location in the dentate gyrus and appearance characteristic of granule cells, or by the presence of typical neuronal processes. Electron microscopic examination of ultrathin sections confirmed that the electron-dense $\mathrm{X}$-gal reaction product was localized predominantly in neurons (Fig. 3), This result is in agreement with the fact that a late gene promoter is responsible for driving lac $Z$ expression. Thus, both $\beta$-gal activity and viral particles are observed in the same cell. Few enveloped particles were observed in the cytoplasm, however, supporting the limited replication of the mutant virus.

Stereotactic inoculation of either $5 \mu$ l of media containing $10^{7} \mathrm{pfu} / \mathrm{ml}$ wild-type HSV-1 (KOS) or a similar dose of a glycoprotein $\mathrm{C}$ deletion mutant, $\mathrm{gC}^{-} 39$, described earlier (Sunstrum et al., 1988; Chrisp et al., 1989) caused death at 2-3 weeks post inoculation in two-thirds of the injected rats. Surviving animals, sacrificed at 3 weeks to 3 months after inoculation, often showed focal encephalomalacia as a result of brain destruction by those viruses of unattenuated pathogenicity. In contrast, the Us3::pgC-lacZ recombinant showed only limited disruption of the normal neuronal architecture in animals examined 4 weeks to 20 months after inoculation (Fig. 4).

To determine whether the Us3::pgC-lacZ vector persisted in the brain, the PCR (Saiki et al., 1985) was used to amplify viral-specific DNA and RNA isolated from the brain of rats sacrificed from 2 days to 10 months after inoculation. PCR analyses were performed using three different primer pairs (Fig. 5). Using Us $3:: p g C-l a c Z$ viral DNA as template in 40 cycles of PCR amplification, the primer pairs generate bands of the following lengths: $\mathrm{LAT}=195 \mathrm{bp}$; lacZ $=324 \mathrm{bp} ; \mathrm{gB}=191 \mathrm{bp}$ (data not shown). The LAT primer set has been used previously to detect LAT RNA in latently infected trigeminal ganglia (Lynas et al., 1989). Each primer pair generated an appropriate length band using template DNA isolated from animals sacrificed 2 days, 7 days, and 10 months p.i., but not from DNA isolated from uninoculated controls. An example showing amplification of viral DNA from brain with the lac $Z$ primer pair is shown (Fig. 5A, top). Specificity of the bands was confirmed by Southern blot analysis (Fig. 5A, bottom) (Haggi et al., 1988).

To evaluate viral-specific gene expression in brain, RNA isolated at various times post injection was reacted with the appropriate $3^{\prime}$ primer in the presence of AMV reverse transcriptase (RT) to generate cDNA, which was then used as the template for DNA PCR amplifications (Kawasaki et al., 1988). Because the LAT 3 ' primer is antisense with respect to LAT but sense with regards to ICPO, this primer will only generate cDNAs to LAT. An additional primer pair, specific for the $\alpha 2$ isoform of the cellular $(\mathrm{Na}, \mathrm{K})$-ATPase gene, included as an internal control, confirmed that RNA isolated was intact (data not shown). Samples lacking AMV RT, included as controls for the efficiency of the DNase treatment, failed to generate PCR product. LAT RNA was detected in brains of animals sacrificed 2 days, 7 days, and 10 months post-inoculation, consistent with expression of LAT during lytic viral replication and from latent viral genomes (Fig. 5C). mRNA for lacZ (Fig. 5B) and gB (Fig. 5D) were only detected in RNA from the 2-day and 7-day post-inoculation brains, but were not detected in RNA from the 10-month post-inoculation brains, consistent with the shut-off of lytic gene expression during latency (Stevens, 1989).

\section{DISCUSSION}

These experiments were designed to determine whether an attenuated replication-competent HSV vector could be used to express a foreign gene product and establish latency in a specific region of the brain. Previous studies had demonstrated the potential utility of HSV-based vectors to express foreign genes in neurons in vitro and in vivo. The expression of the human HPRT mRNA in mouse brain from a replicating $\mathrm{tk}^{-}$derivative of HSV-1 has been reported, although long-term expression and pathogenesis of the vector were not examined (Pallela et al. 1989). HSV-packaged amplicons have also been used as gene transfer vectors in vitro (Geller and Breakefield, 1988; Geller and Freese, 1990) and replication-incompetent HSV vectors in neurons that project to the periphery (Dobson et al., 1990). Due to the limitations of these systems, they do not represent ideal gene transfer vehicles for the CNS. A prerequisite for a useful gene transfer vector is foreign gene expression in a significant number of neurons in discrete brain regions in vivo, which could be achieved through use of a replicating highly attenuated mutant.

Our results indicate that stereotactic injection of an attenuated virus directly into the brain provides a useful means of targeting an HSV-mediated vector to a specific brain region. 
With the Us3-defective virus, lacZ expression was transient and limited to the injection site. Because lac $Z$ expression in this recombinant is driven by a viral late gene $(\mathrm{gC})$ promoter, this result implies that viral replication was transient and limited to the injection site. This might represent a failure of viral transport to distant brain sites, or a failure to replicate following axonal transport. A second correlate of decreased neurovirulence is limited cell-to-cell spread in the hippocampus, resulting in little apparent disruption of normal brain architecture. Although a detailed analysis was not carried out, electron microscopy of the infected hippocampus 2 days post-injection showed an abundance of nonenveloped nucleocapsids in the nucleus with few enveloped viral particles in the cytoplasm. Additionally, infectious particles were recovered from brain paste up to 4 days post-inoculation but not at times greater than 7 days (data not shown). Together, these findings suggest that infection by a Us3-defective virus is selflimited.

The expression of lacZ within neurons in the brain shows that the HSV gene transfer vector can be used to express a foreign gene in vivo in the rat CNS. The PCR data indicate that the vector persists in the brain and continues to express the LAT transcript, the hallmark of latency. These findings provide evidence for in vivo LAT promoter activity in brain in the absence of expression of either viral or recombinant genes driven by lytic cycle promoters after direct intracranial inoculation. In a previous study, Chiocca et al. (1990) performed stereotactic CNS inoculations using defective (ICP4 ${ }^{-}$) and attenuated $\left(\mathrm{ICPO}^{-}\right)$mutants possessing lacZ reporter gene cassettes driven by lytic gene promoters (ICP6 and ICPO, respectively). Foreign gene expression was transient and the attenuated mutant displayed limited virus spread without causing death of the inoculated animal, similar to our results with the Us3 mutant. Neither long-term virus-mediated pathology nor long-term persistence latent virus were determined. Attempts to reactivate the Us3 mutant virus from brain by cocultivation have proven unsuccessful, in agreement with the results of Deatly et al. (1988) who were unable to reactivate wild-type virus from the CNS after establishement of latency by peripheral inoculation. Attempts to reactivate the Us3 mutant virus from the trigeminal ganglia of rats infected by corneal scarification have also failed, suggesting that the Us3 gene product may play a role in virus reactivation from the PNS (L. Sternberg, unpublished). The DNA PCR analyses showed that viral sequence representing the LAT, gB, and Us3 (lacZ) loci were present in latently infected 10 -month animals. Although we have not demonstrated the existence of the entire viral genome in the latent state, the expression of LAT in brain suggests that other genes under the control of the LAT promoter could be expressed long-term with this vector. Recent experiments using the $l a c Z$ gene under control of an HSV-1 LAT promoter have confirmed these predictions (W.F. Goins, R.L. Hendricks, L.R. Sternberg, D.J. Fink, and J.C. Glorioso, in preparation). Thus, by placing foreign gene expression under the control of the HSV LAT or neuronal cell-specific promoters, this vector may be useful for the transfer and continuous expression of foreign genes in the brain. Similarly engineered vectors are currently in use in our laboratory for introducing a variety of cellular genes into the brain for studies of fundamental aspects of CNS biology and gene expression.

\section{ACKNOWLEDGMENTS}

We acknowledge the excellent technical assistance of Michael W. Beaty in histology, and Diane Alessi and Nancy Kupina in electron microscopy. This work was supported by grants from the VA (D.J.F., M.M.), NINDS (NF 27771, D.J.F.), and NIGMS (GM34534, J.C.G.).

\section{REFERENCES}

BAK, I.J., MARKHAM, C.H., COOK, M.L., and STEVENS, J.G. (1977). Intraaxonal transport of herpes simplex virus in the rat central nervous system. Brain Res. 136, 415-429.

BREAKEFIELD, X.O., and GELLER, A.I. (1987). Gene transfer into the nervous system. Mol. Neurobiol. 1, 339-371.

CHIOCCA, E.A., CHOI, B.B., CAI, W., DELUCA, N.A., SCHAFFER, P.A., DIFIGLIA, M., BREAKEFIELD, X.O., and MARTUZA, R.L. (1990). Transfer and expression of the lacZ gene in rat brain neurons mediated by herpes simplex mutants. New Biol. 2, 739-746.

CHRISP, C.E., AVERILL, D.R., SUNSTRUM, J.C., LEVINE, M., and GLORIOSO, J.C. (1989). Characterization of enchephalities in adult mice induced by intracerebral inoculation of herpes simplex virus type 1 (KOS) and comparison with mutants showing decreased virulence. Lab. Invest. 60, 822-830.

COOK, M.L., and STEVENS, J.G. (1973). Pathogenesis of herpetic neuritis and ganglionitis in mice: Evidence for intra-axonal transport of infection. Infect. Immun. 7, 272-288.

DEATLY, A.M., SPIVACK, J.G., LAVI, E., and FRASER, N.W. (1987). RNA from an immediate early region of the type 1 herpes simplex virus genome is present in the trigeminal ganglia of latently infected mice. Proc. Natl. Acad. Sci. USA 84, 3204-3208.

DEATLY, A.M., SPIVACK, J.G., LAVI, E., O'BOYLE II, D.R., and FRASER, N.W. (1988). Latent herpes simplex virus type 1 transcripts in peripheral and central nervous system tissues of mice map to similar regions of the viral genome. J. Virol. 62, 749-756.

DOBSON, A.T., MARGOLIS, T.P., SEDARATI, F., STEVENS, J.G. and FELDMAN, L.T. (1990). A latent, nonpathogenic HSV-1derived vector stably expresses beta-galactosidase in mouse neurons. Neuron 5, 353-360.

EFSTATHIOUS, S., MINSON, A.C., FIELD, H.J., ANDERSON, J.R., and WILDY, P. (1986). Detection of herpes simplex virusspecific DNA sequences in latently infected mice and in humans. J. Virol. 57, 446-455.

FREESE, A., GELLER, A.I., and NEVE, R. (1990). HSV-1 vector mediated neuronal gene delivery: Strategies for molecular neuroscience and neurology. Biochem. Pharmacol. 40, 2189-2199.

GELLER, A.I., and BREAKEFIELD, X.O. (1988). A defective HSV-1 vector expresses Escherichia coli $\beta$-galactosidase in cultured peripheral neurons. Science 241, 1667-1669.

GELLER, A.I., and FREESE, A. (1990). Infection of cultured central nervous system neurons with a defective herpes simplex virus 1 vector results in stable expression of Escherichia coli beta-galactosidase. Proc. Natl. Acad. Sci. USA 87, 1149-1153.

GOINS, W.F. and STINSKI, M.F. (1986). Expression of a human cytomegalovirus late gene is post-transcriptionally regulated by a 3 '-end processing event occurring exclusively late after infection. Mol. Cell. Biol. 6, 4202-4213.

HAGGI, T.M., SARKAR, G., DAVID, C.S., and SOMMER, S.S. (1988). Specific amplification with PCR of a refractory segment of genomic DNA. Nucleic Acids Res. 16, 11844-11844.

HATCHER, S.L.S., TEPLITZ, R.L., and ELROD, S.L. (1990). Rapid alkaline trasfer of low-molecular weight DNA from NuSieve GTG agarose gels. BioTechniques 9, 260-262. 
HENDRICKS, R.L., WEBER, P.C., TAYLOR, J.L., KOUMBIS, A. TUMPEY, T.M., and GLORIOSO, J.C. (1991). Endogenously produced interferon $\alpha$ protects mice from herpes simplex virus type 1 corneal disease. J. Gen. Virol. 72, 1601-1610.

HILL, T.J. (1985). Herpes simplex virus latency. In The Herpesviruses. B. Roizman, ed. (Plenum Press, New York) pp. 175-240.

HO, D.Y., and MOCARSKI, E.S. (1989). Herpes simplex virus latent RNA (LAT) is not required for latent infection in the mouse. Proc. Natl. Acad. Sci. USA 86, 7596-7600.

HOMA, F.L., O'TAL, T.M., GLORIOSO, J.C., and LEVINE, M. (1986). Transcriptional control signals of the herpes simplex virus type 1 late $\left(\gamma_{2}\right)$ gene lie within bases -34 to +124 relative to the 5 '-terminus of the mRNA. Mol. Cell. Biol. 6, 3652-3666.

ITAKURA, K. (1982). Chemical synthesis of genes. Trends Biochem. Sci. 7, 442-445.

KAWASAKI, E.S., CLARK, S.S., COYNE, M.Y., SMITH, S.D., CHAMPLIN, R., WITTE, O.N., and MCCORMICK, F.P. (1988). Diagnosis of chronic myeloid and acute lymphocytic leukemias by detection of leukemia-specific mRNA sequences amplified in vitro. Proc. Natl. Acad. Sci. USA 85, 5698-5702.

LEADER, D.P., and KATAN, M. (1988). Viral aspects of protein phosphorylation. J. Gen. Virol. 69, 1441-1464.

LEADER, D.P., and PURVES, F.C. (1988). The herpesvirus protein kinase: a new departure in protein phosphorylation? Trends Biochem. Science 13, 244-246.

LEIB, D.A., BOGARD, C.L., KOSZ-VNENCHAK, M., HICKS, K.A., COEN, D.M., KNIPE, D.M., and SCHAFFER, P.A. (1989). A deletion mutant of the latency-associated transcript of herpes simplex virus type 1 reactivates from the latent state with reduced frequency. J. Virol. 63, 2893-2900

LONGNECKER, R., and ROIZMAN, B. (1987). Clustering of genes dispensible for growth in culture in the S component of the HSV-1 genome. Science 236, 573-576.

LYNAS, C., LAYCOCK, K.A., COOK, S.C., HILL, T.J., BLYTH, W.A., and MAITLAND, N.J. (1989). Detection of herpes simplex virus type 1 gene expression in latently and productively infected mouse ganglia using the polymerase chain reaction. J. Gen. Virol. 70, 2345-2355.

MCFARLAND, D.J., SIKORA, E., and HOTCHIN, J. (1986). The production of focal herpes encephalitis in mice by stereotaxic inoculation of virus: Anatomical and behavioral effects. J. Neurol. Sci. 72, 307-318.

MCGEOCH, D.J., DOLAN, A., DONALD, S., and RIXON, F.J. (1985). Sequence determination and genetic content of the shor unique region in the genome of herpes simplex virus type 1. J. Mol. Biol. 181, 1-13.

MEIGNIER, B., LONGNECKER, R., MAVROMARA-NAZOS, P. SEARS, A.E., and ROIZMAN, B. (1988). Virulence of and establishment of latency by genetically engineered deletion mutants of herpes simplex virus 1. Virology 162, 251-254.

MELLERICK, D.M., and FRASER, N.W. (1987) Physical state of the latent herpes simplex virus genome in a mouse model system: Evidence suggesting an episomal state. Virology 158, 265-275.

PALLELA, T.D., HIDAKA, Y., SILVERMAN, L.J., LEVINE, M., GLORIOSO, J.C., and KELLEY, W.N. (1989). Expression of human HPRT mRNA in brains of mice infected with a recombinant herpes simplex virus-1 vector. Gene 80, 137-144.

PAXINOS, G., and WATSON, C. (1982). The Rat Brain in Stereotaxic Coordinates. (Academic Press, New York).

PUGA, A., and NOTKINS, A.L. (1987). Continued expression of a poly $(\mathrm{A})^{+}$transcript of herpes simplex virus type 1 in trigeminal ganglia of latently infected mice. J. Virol. 61, 1700-1703.

PURVES, F.C., LONGNECKER, R.M., LEADER, D.P. and ROIZMAN, B. (1987). Herpes simplex virus 1 protein kinase is encoded by open reading frame Us 3 which is not essential for virus growth in cell culture. J. Virol. 61, 2896-2901.
PURVES, F.C., SPECTOR, D., and ROIZMAN, B. (1991). The herpes simplex virus 1 protein kinase encoded by the Us3 gene mediates posttranslational modification of the phosphoprotein encoded by the UL34 gene. J. Virol. 65, 5757-5764.

ROCK, D.L., and FRASER, N.W. (1983). Detection of HSV-1 genome in central nervous system of latently infected mice. Nature 302, 523-525.

ROCK, D.L., NESBER, A.B., GHIASI, H., ONG, J., LEWIS, T.L., LOKENSGARD, J.R., and WECHSLER, S. (1987). Detection of latency-related viral RNAs in trigeminal ganglia of rabbits latently infected with herpes simplex virus type 1. J. Virol. 61, 3820-3826.

SAIKI, R.K., SCHARF, S., FALOONA, F., MULLIS, K.B., HORN, G.T., ERLICH, H.A., and ARNHEIM, N. (1985). Enzymatic amplification of beta-globin genomic sequences and restriction site analysis for diagnosis of sickle cell anemia. Science 230, 1350-1354.

SEDARATI, F., IZUMI, K.M., WAGNER, E.K., and STEVENS, J.G. (1989). Herpes simplex virus type 1 latency-associated transcription plays no role in establishment or maintenance of a latent infection in murine sensory neurons. J. Virol. 63, 4455-4458.

SHAPIRA, M., HOMA, F.L., GLORIOSO, J.C., and LEVINE, M. (1987). Regulation of the herpes simplex type 1 late $\left(\gamma_{2}\right)$ glycoprotein $C$ gene: Sequence between base pairs -34 to +29 control expression and responsiveness to transactivation by the products of the immediate early $(\alpha) 4$ and 0 genes. Nucleic Acids Res. 15, 30973111 .

SPIVACK, J.G., and FRASER, N.W. (1987). Detection of herpes simplex virus type 1 transcripts during latent infection in mice. $J$. Virol. 61, 3841-3847.

STEINER, I., SPIVACK, J.G., LIRETTE, R.P., BROWN, S.M., MACLEAN, A.R., SUBAK-SHARPE, J., and FRASER, N.W. (1989). Herpes simplex virus type 1 latency-associated transcripts are evidently not essential for latent infection. EMBO J. 8, 505-511.

STEVENS, J.G. (1989). Human herpesviruses: a consideration of the latent state. Microbiol. Rev. 53, 318-332.

STEVENS, J.G., WAGNER, E.K., DEVI-RAO, G.B., COOK, M.L., and FELDMAN, L.T. (1987). RNA complementary to a herpesvirus gene mRNA is prominent in latently infected neurons. Science $\mathbf{2 3 5}$, 1056-1059.

STROOP, W.G., and SCHAEFER, D.C. (1987). Herpes simplex virus, type 1 invasion of the rabbit and mouse nervous systems revealed by in situ hybridization. Acta Neuropathol. 74, 124-132.

SUNSTRUM, J.C., CHRISP, C.E., AVERILL, D.R., LEVINE, M., and GLORIOSO, J.C. (1988). Pathogenicity of glycoprotein C negative mutants of herpes simplex virus type 1 for the mouse central nervous system. Virus Res. 11, 17-32.

WAGNER, E., DEVI-RAO, G., FELDMAN, L., DOBSON, A., ZHANG, G., FLANAGAN, M., and STEVENS, J. (1988). Physical characterization of the herpes simplex virus latency-associated transcript in neurons. J. Virol. 62, 1194-1202.

WEBER, P.C., LEVINE, M., and GLORIOSO, J.C. (1987). Rapid identification of nonessential genes of herpes simplex virus type 1 by Tn5 mutagenesis. Science 236, 576-579.

Address reprint requests to: Dr. Joseph C. Glorioso Professor and Chairman Department of Molecular Genetics and Biochemistry University of Pittsburgh School of Medicine E1246 Biomedical Science Tower Pittsburgh, PA 15261

Received for publication September 11, 1991; accepted after revision November 12, 1991. 


\section{This article has been cited by:}

1. Thais Federici, Nicholas M. Boulis. 2006. Gene-based treatment of motor neuron diseases. Muscle \& Nerve 33:3, 302-323. [CrossRef]

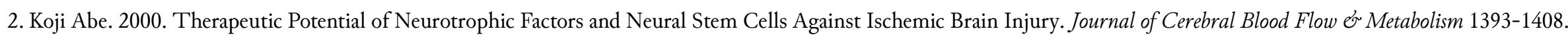
[CrossRef]

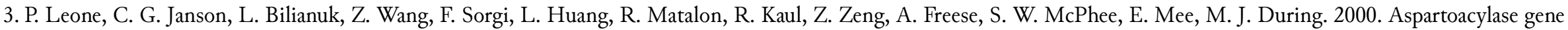
transfer to the mammalian central nervous system with therapeutic implications for Canavan disease. Annals of Neurology 48:1, 27-38. [CrossRef]

4. David S Strayer. 2000. Viral gene delivery. Expert Opinion on Investigational Drugs 8:12, 2159-2172. [CrossRef]

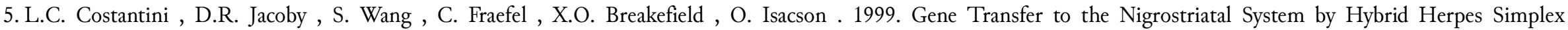

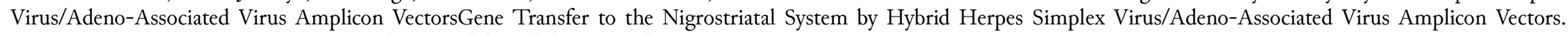
Human Gene Therapy 10:15, 2481-2494. [Abstract] [PDF] [PDF Plus]

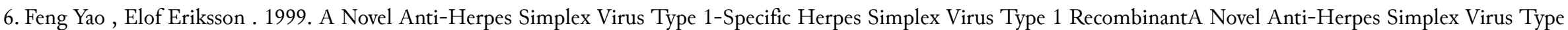
1-Specific Herpes Simplex Virus Type 1 Recombinant. Human Gene Therapy 10:11, 1811-1818. [Abstract] [PDF] [PDF Plus]

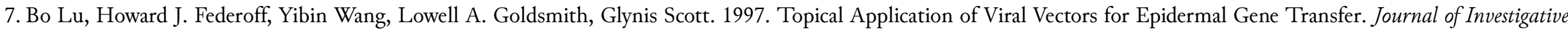
Dermatology 108:5, 803-808. [CrossRef]

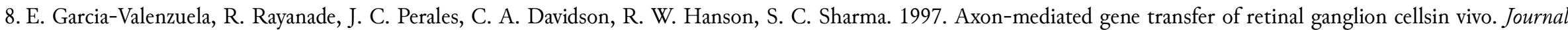
of Neurobiology 32:1, 111-112. [CrossRef]

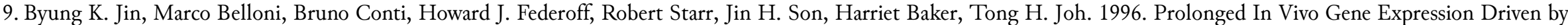

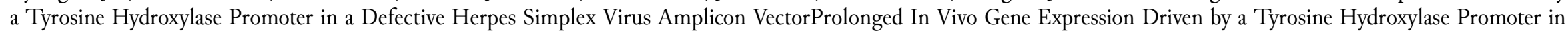
a Defective Herpes Simplex Virus Amplicon Vector. Human Gene Therapy 7:16, 2015-2024. [Abstract] [PDF] [PDF Plus]

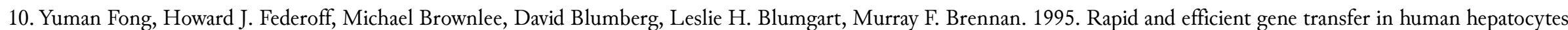
by herpes viral vectors. Hepatology 22:3, 723-729. [CrossRef]

11. Laurie C. Doering. 1994. Nervous system modification by transplants and gene transfer. BioEssays 16:11, 825-831. [CrossRef]

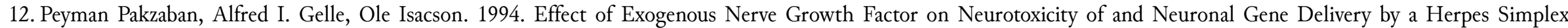

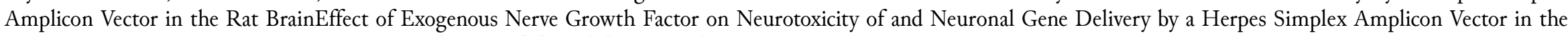
Rat Brain. Human Gene Therapy 5:8, 987-995. [Abstract] [PDF] [PDF Plus]

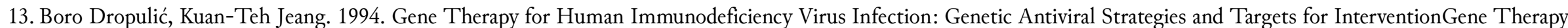

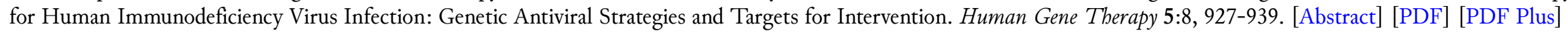

14. Fred D. Ledley. 1993. Hepatic gene therapy: Present and future. Hepatology 18:5, 1263-1273. [CrossRef]

15. David A. Leib, Paul D. Olivo. 1993. Gene delivery to neurons: Is herpes simplex virus the right tool for the job?. BioEssays 15:8, 547-554. [CrossRef]

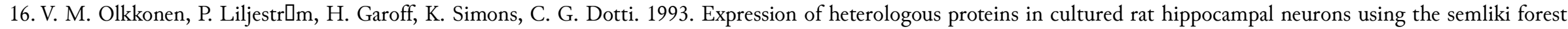
virus vector. Journal of Neuroscience Research 35:4, 445-451. [CrossRef]

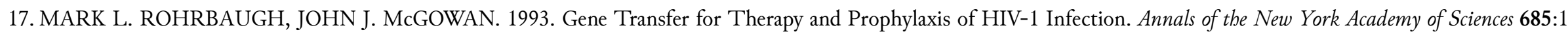
Immunomodulat, 697-712. [CrossRef] 
18. Shoushu Jiao, Liang Cheng, Jon A. Wolff, Ning-Sun Yang. 1993. Particle Bombardment-Mediated Gene Transfer and Expression in Rat Brain Tissues. Bio/Technology 11:4, 497-502. [CrossRef]

19. Saï Akli, Catherine Caillaud, Emmanuelle Vigne, Leslie D. Stratford-Perricaudet, Livia Poenaru, Michel Perricaudet, Axel Kahn, Marc R. Peschanski. 1993. Transfer of a foreign gene into the brain using adenovirus vectors. Nature Genetics 3:3, 224-228. [CrossRef]

20. Xandra Owens Breakefield. 1993. Gene delivery into the brain using virus vectors. Nature Genetics 3:3, 187-189. [CrossRef]

21. Beverly L. Davidson, Edward D. Allen, Karen F. Kozarsky, James M. Wilson, Blake J. Roessler. 1993. A model system for in vivo gene transfer into the central nervous system using an adenoviral vector. Nature Genetics 3:3, 219-223. [CrossRef] 